\title{
Accumulation of madecassoside - a major component of centelloside - in centella (Centella asiatica (L.) Urban) cells elicited by salicylic acid
}

\author{
NGUYEN HOANG LOC ${ }^{1 *}$ \\ NGUYEN THANH GIANG ${ }^{2}$ \\ NGUYEN DUC HUY? \\ TRUONG THI PHUONG LAN ${ }^{3}$ \\ ${ }^{1}$ College of Sciences, Hue University, Hue 530000 \\ Vietnam \\ ${ }^{2}$ Institute of Biotechnology, Hue University \\ Hue 530000, Vietnam \\ ${ }^{3}$ College of Medicine and Pharmacy, Hue University, \\ Hue 530000, Vietnam \\ *Correspondence: \\ Nguyen Hoang Loc \\ E-mail:nhloc@hueuni.edu.vn
}

Keywords: Centella asiatica, madecassoside, elicitor, salicylic acid, triterpenoid

Received July 8, 2016.

Revised October 25, 2016.

Accepted October 27, 2016.

\begin{abstract}
Background and Purpose: Use of elicitors is one of the most important methods to increase the production of secondary metabolites in plants. Salicylic acid is a common chemical elicitor and also a signalling molecule in the signal transduction systems, stimulating biosynthesis of enzymes. However, its influence on the accumulation of madecassoside, a valuable bioactive compound, in centella cell cultures remains uncharacterized.
\end{abstract}

Materials and Methods: Callus of centella (Centella asiatica (L.) Urban) was used to establish cell suspension culture on the MS (Murashige and Skoog 1962) medium supplemented with $2 \mathrm{mg} / \mathrm{L}$ 2,4-dichlorophenoxyacetic acid and $3 \mathrm{mg} / \mathrm{L}$ thidiazuron. The cell biomass was harvested after 24 days of culture. Concentrations of salicylic acid from 50 to $200 \mu \mathrm{M}$ were added to the medium at the beginning of cell culture. The timing of $100 \mu \mathrm{M}$ salicylic acid addition on days 5, 10 or 15 after inoculation was also studied. Callus growth and biosynthesis of madecassoside in centella cells were characterized.

Results and Conclusions: The cell fresh (dry) biomass increased from the $3 \mathrm{rd}$ to 24 th day to a maximum of $8.1 \pm 0.4 \mathrm{~g} /$ flask $(0.95 \pm 0.05 \mathrm{~g} /$ flask $)$. The highest madecassoside concentration of $27 \pm 0.7 \mathrm{mg} / \mathrm{g}$ dry weight was also obtained on the 24th day of culture. The cell growth was inhibited with salicylic acid additions at the beginning of culture (day 0), reaching the minimum at $200 \mu M$ salicylic acid. However, biosynthesis of madecassoside was significantly enhanced at all salicylic acid concentrations, with the maximum $(82 \pm 3.5 \mathrm{mg} / \mathrm{g}$ dry weight) reached at $100 \mu \mathrm{M}$ salicylic acid. The growth of cells treated with $100 \mathrm{uM}$ salicylic acid was the lowest when salicylic acid was added at the beginning of the culture and the highest when the addition was postponed until day 15 (harvested on day 24). The madecassoside concentration reached as high as $114 \pm 3.1 \mathrm{mg} / \mathrm{g}$ dry weight in the treatment with 100 $\mu M$ salicylic acid added after 10 days of culture (a 4-fold increase compared with the control without salicylic acid). In general, salicylic acid is effective in enhancing biosynthesis of madecassoside in centella cells.

\section{INTRODUCTION}

Centella (Centella asiatica (L.) Urban) is a small and aromatic-smell-

ing species of the Apiaceae family native to tropical and subtropical regions such as southeast Asia, India, Sri Lanka as well as South Africa and Madagascar (1). Centella contains many valuable secondary compounds, especially centellosides (madecassoside, asiaticoside, madecassic acid and asiatic acid) belonging to triterpenoids (2). The centellosides (also known as triterpene saponins) have a wide range of pharmaco- 
logical applications, such as the antiplatelet, hypocholesterolemic, antitumoral, anti-HIV, immunoadjuvant, antiinflammatory, antibacterial, insecticide, fungicide and anti-leishmanial agents (3).

Application of elicitors is one of the most important methods to increase the production of secondary metabolites in plants (4). There were some reports on in vitro cultures of centella treated by methyl jasmonate (MJ) to improve the biosynthesis of triterpene saponins: for example, stimulation of asiaticoside production in plantlets (5) and hairy-root cultures (6) by MJ, effect of MJ on triterpene metabolisms of planlets (7), centelloside production in cells elicited by MJ (8), and metabolomic analysis of MJ-induced triterpenoid production in cells (9). However, there are no reports on the effects of salicylic acid (SA), a common chemical elicitor in plant (10), on the accumulation of madecassoside in centella cell cultures. Meanwhile, many studies used SA to improve the biosynthesis of important metabolic compounds in cell or hairy-root cultures of different plant species, e.g. jaceosidin and siringin from Saussurea medusa (11), flavonolignans and lipoxygenase from Silybum marianum (12), phenolic metabolism in Matricaria chamomilla (13), metabolic changes of Catharanthus roseus cell cultures (14), podophyllotoxin from Linum album (15), and taxol from Taxus baccata (16). In a previous report, we showed a stimulatory effect of SA on the biosynthesis of asiaticoside in centella cells (17). This study was aimed at investigating the role of SA in accumulation of another important component of centelloside, that is madecassoside.

\section{MATERIALS AND METHODS}

\section{Plant materials}

Callus of centella (Centella asiatica (L.) Urban) was used to establish cell suspension culture as described pre-

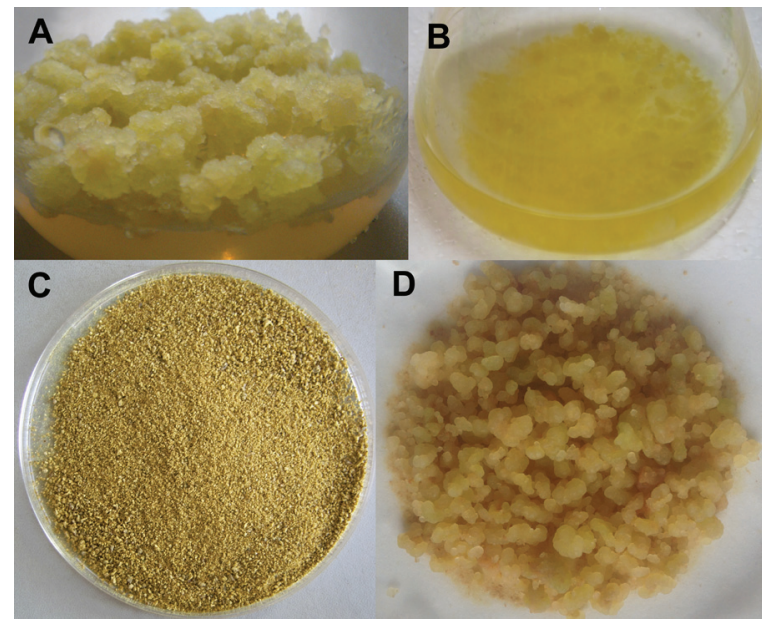

Figure 1. A: Calli of centella. B: Centella suspension cells. C and D: Dry and fresh biomass of centella cells after 24 days of cuture.

viously (17) with some modifications on component and concentration of plant growth regulators including 2 $\mathrm{mg} / \mathrm{L}$ 2,4-D (2,4-dichlorophenoxyacetic acid) and 3 $\mathrm{mg} / \mathrm{L}$ TDZ (thidiazuron). Centella suspension cells were cultured in $250 \mathrm{~mL}$ Erlenmeyer flasks containing $50 \mathrm{~mL}$ of nutrient medium with an inoculum size $3 \mathrm{~g}$, shaking speed $120 \mathrm{rpm}$, light intensity 360 lux and temperature $25 \pm 2^{\circ} \mathrm{C}$ for 18 days (Fig 1) to produce sufficient starting biomass.

\section{Salicylic acid elicitation}

Elicitation effect of $S A$ was studied by adding different concentrations $(50-200 \mu \mathrm{M})$ to the medium at the beginning of 18-day-old cell culture (day 0 ) (experiments 1 and 2, Figs 2-3), and days 5, 10 or 15 after inoculation (experiment 3, Fig 4) with culture conditions similar to those described above for biomass production. The elicited cells were harvested after 30 days (Fig 2) or 24 days
Figure 2. Growth and madecassoside production by centella cells as influenced by duration of culture. For each mean, \pm standard error bars are shown. Different letters indicate significantly different means (Duncan's test, $\mathrm{p} \leq 0.05$ ).

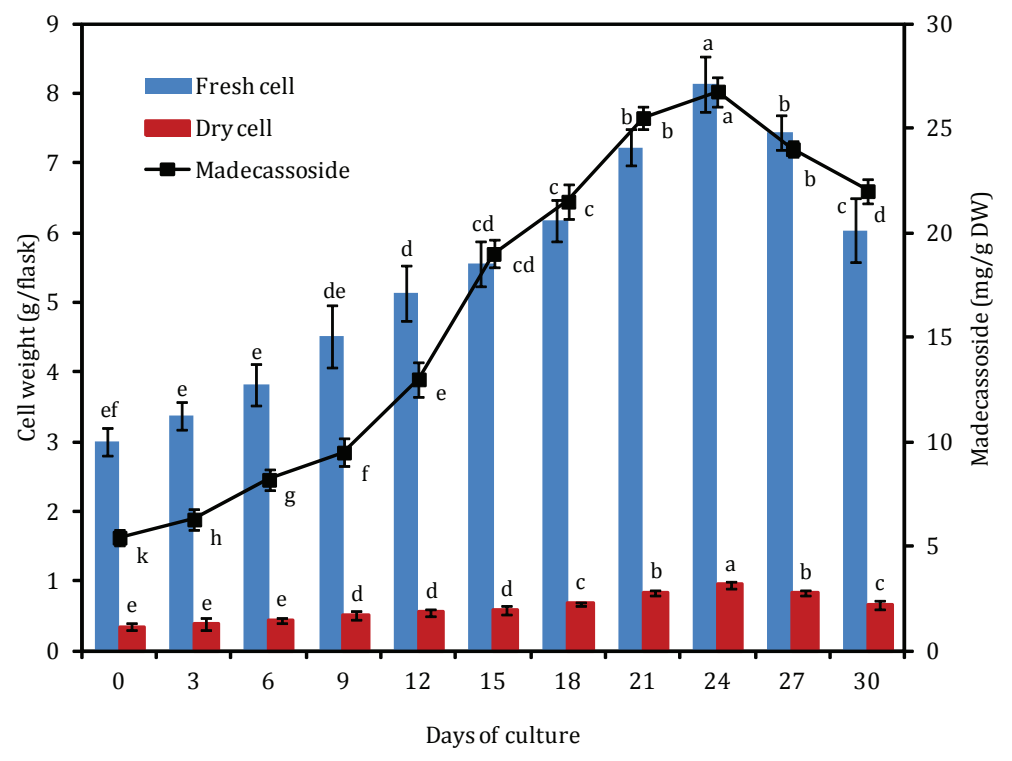

Period biol, Vol 119, No 1, 2017. 


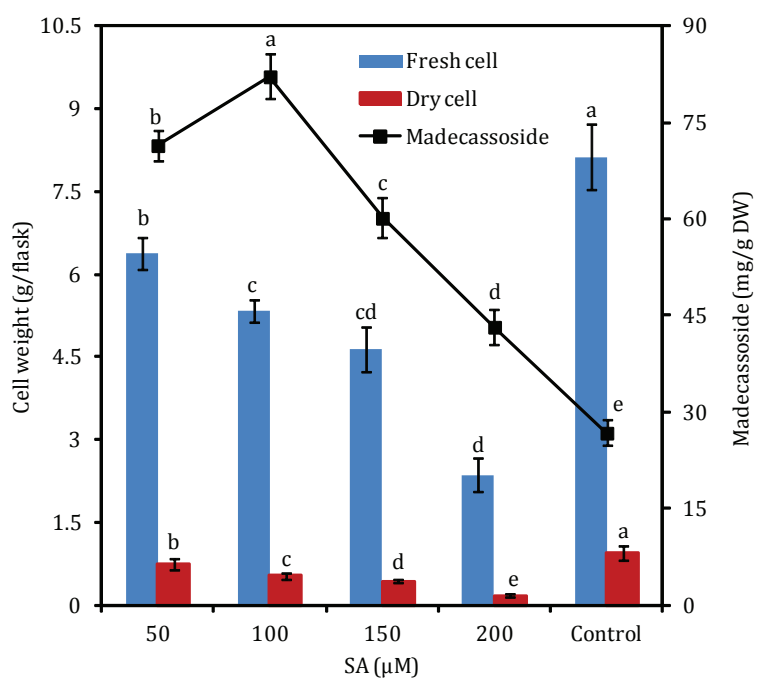

Figure 3. Effect of SA concentration (50-200 $\mu \mathrm{M})$ on growth and madecassoside production by centella cells after 24 days of culture. $S A$ was added to the medium at the beginning of culture. Control: non-elicited cells. For each mean, \pm standard error bars are shown. Different letters indicate significantly different means (Duncan's test, $\mathrm{p} \leq 0.05$ ).

(Figs 3-4) by filtration; concentration of madecassoside was quantified by high performance liquid chromatography (HPLC).

\section{Quantification of madecassoside}

Fresh cell biomass was dried at $50^{\circ} \mathrm{C}$ to a constant weight, then ground into a fine powder. One gram of the powder was soaked in $10 \mathrm{~mL}$ of $90 \% \mathrm{v} / \mathrm{v}$ ethanol for $48 \mathrm{~h}$. The extract was then filtered and concentrated at $70^{\circ} \mathrm{C}$ using a vacuum rotary concentrator (Heidolph, Germany). The concentrate was dissolved in $10 \mathrm{~mL}$ of $100 \%$ ethanol, filtered through Minisart $0.25 \mu \mathrm{m}$ membranes (Sartorius, Germany), and diluted 5-fold. An aliquot of 20 microliters of diluted extract was subjected to HPLC equipped with a LiChrospher $18 \mathrm{e}$ column $(5 \mu \mathrm{m}, 4 \mathrm{~mm} \times 250 \mathrm{~mm})$, flow rate of $1 \mathrm{~mL} / \mathrm{min}$, run time of $10 \mathrm{~min}$, detector wavelength of $254 \mathrm{~nm}$, stationary phase of silica gel (reverse phase) and mobile phase of ethanol:water (6:4 ratio). A standard curve of madecassoside (purchased from Sigma, USA) was used for determination of madecassoside concentration in the extract. HPLC analysis was performed on a LC-20A Prominence system (Shimadzu, Japan). All solvents and standard chemicals were of analytical grade and were purchased from Sigma (USA) and Chromadex (USA).

\section{Statistical analysis}

All experiments were repeated at least three times, and the representative data were shown. The means of samples were compared using one-way ANOVA followed by Duncan's test at $p \leq 0.05$.

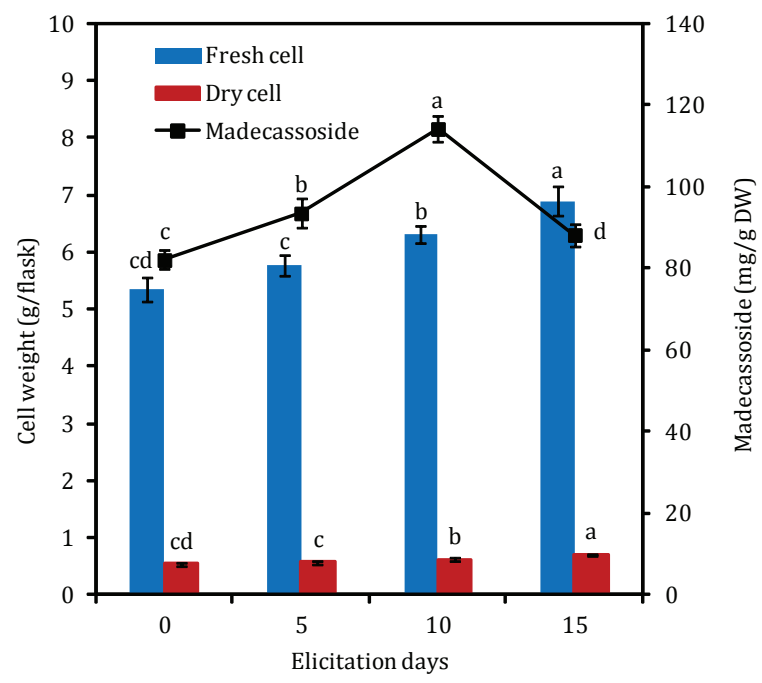

Figure 4. Effect of timing of $100 \mu M S A$ addition on growth and madecassoside production by centella cells after 24 days of culture. 0: SA was added to the medium at the beginning of culture. 5, 10 or 15: SA was added to the medium after 5, 10 or 15 days of culture. For each mean, \pm standard error bars are shown. Different letters indicate significantly different means (Duncan's test, $\mathrm{p} \leq 0.05$ ).

\section{RESULTS}

\section{Effect of SA concentration}

The cell fresh (dry) biomass increased from the 3rd to 24 th day to a maximum of $8.1 \pm 0.4 \mathrm{~g} / \mathrm{flask}(0.95 \pm 0.05 \mathrm{~g} /$ flask) (Fig 2), the values 1.35- (1.67-) fold higher compared with those achieved on the MS medium supplemented with $1 \mathrm{mg} / \mathrm{L}$ BAP (benzylaminopurine) and $1 \mathrm{mg} / \mathrm{L}$ NAA (naphthaleneacetic acid) in our previous study (17). The dynamics of madecassoside accumulation was similar to that of the cell growth, with the highest concentration of $27 \pm 0.7 \mathrm{mg} / \mathrm{g}$ dry weight (DW) obtained on the $24 \mathrm{th}$ day of culture.

Different concentrations of SA were added to the medium at the beginning of culture. The callus growth was significantly inhibited with SA addition, reaching the minimum at $200 \mu \mathrm{M}$ SA (Fig 3). Biosynthesis of madecassoside was enhanced significantly at all SA concentrations, with the maximum reached at $100 \mu \mathrm{M}$ SA (almost 3-fold higher than in the non-elicited cells, Fig 3). This SA concentration was used in further experiments to study the effect of timing of SA addition.

\section{Effect of elicitation day}

An addition of $100 \mu \mathrm{M}$ SA at days 0,5 or 10 days resulted in decreased cell growth compared with the addition on day 15 (Fig 4).

The optimum SA addition for elicitation of madecassoside production was the 10th day of culture. The dynamics of madecassoside accumulation in the elicited and non-elicited cells was similar (data not shown). 


\section{DISCUSSION}

According to Dučaiová et al (18), SA is considered a potent phytohormone because of its key regulatory roles in plant metabolism. It is also a signalling molecule in the signal transduction systems, stimulating the biosynthesis of special enzymes for reactions forming defense compounds such as terpenoids (including triterpene saponins), phenols, alkaloids or pathogenesis-related proteins $(19,20)$.

The elicitor role of exogenous SA was studied in plant cell cultures regarding accumulation of secondary metabolites. According to Li et al (21), the SA treatment also slightly inhibited the growth of Salvia miltiorrhiza cell cultures. Bulgakov et al (22) found earlier that increasing the SA concentrations in the media strongly suppressed the growth of Rubia cordifolia callus cultures.

The results of the present study are consistent with previous studies on the stimulatory effect of SA on asiaticoside biosynthesis (17) and the expression of genes (CaSQS, CabAS and CaCYS) associated with the isoprenoid pathway in centella cells (23). CabAS gene coding for $\beta$-amyrin synthase, a key enzyme in biosynthesis of triterpene saponin (madecassoside is a member of this secondary compound group), was more strongly expressed in the cells elicited with $100 \mu \mathrm{M}$ SA on day 10 after inoculation than in the non-elicited control (23). Study of Wen et al (19) in grape berry (Vitis vinifera L. cv. Cabernet Sauvignon) also showed that SA could induce the accumulation of PAL mRNA (phenylalanine ammonia-lyase (PAL) is a key enzyme in the phenylpropanoid pathway).

\section{CONCLUSION}

We found that concentration of $100 \mu \mathrm{M}$ SA significantly decreased growth of centella cells when added on day 10 after inoculation. However, the madecassoside concentration was 4-fold higher than in the non-elicited control.

Acknowledgments: This work was supported by $N a$ tional Foundation for Science and Technology Development (NAFOSTED), Vietnam (Grant number 106.16-2012.80).

\section{REFERENCES}

1. ORHAN IE 2012 Centella asiatica (L.) Urban: From traditional medicine to modern medicine with neuroprotective potential. Evid Based Complement Alternat Med, Article ID 946259

2. AZIZ Z, DAVEY M, POWER J, ANTHONY P, SMITH R, LOWE K 2007 Production of asiaticoside and madecassoside in Centella asiatica in vitro and in vivo. Biologia Plantarum 51:34-42 https://doi.org/10.1007/s10535-007-0008-x

3. YENDO AC, DE COSTA F, GOSMANN G, FEFTT-NETO AG 2010 Production of plant bioactive triterpenoid saponins: elicitation strategies and target genes to improve yields. Mol Biotechnol 46: 94-104 https://doi.org/10.1007/s12033-010-9257-6
4. KUNDU K, ROY A, SAXENA G, KUMAR L, BHARADVAJA N 2016 Effect of different carbon sources and elicitors on shoot multiplication in accessions of Centella asiatica. Med Aromat Plants 5: 251 https://doi.org/10.4172/2167-0412.1000251

5. KIM OT, KIM MY, HONG MH, AHN JC, HWANG B 2004 Stimulation of asiaticoside accumulation in the whole plant cultures of Centella asiatica (L.) Urban by elicitors. Plant Cell Rep 23: 339-344 https://doi.org/10.1007/s00299-004-0826-7

6. KIM OT, BANG KH, SHIN YS, LEE MJ, JUNG SJ, HYUN DY, KIM YC, SEONG NS, CHA SW, HWANG B 2007 Enhanced production of asiaticoside from hairy root cultures of Centella asiatica (L.) Urban elicited by methyl jasmonate. Plant Cell Rep 26: 1941-1949 https://doi.org/10.1007/s00299-007-0400-1

7. MANGAS S, BONFILL M, OSUNA L, MOYANO E, TORTORIELLO J, CUSIDO RM, PINOL MT, PALAZON J 2006 The effect of methyl jasmonate on triterpene and sterol metabolisms of Centella asiatica, Ruscus aculeatus and Galphimia glauca cultured plants. Phytochemistry 67: 2041-2049 https://doi.org/10.1016/j.phytochem.2006.06.025

8. BONFILL M, CUSIDO R, MOYANO E, SYKLOWSKA-BARANEK K, PALAZON J 2010 Centelloside production in Centella asiatica cell suspension cultures elicited with methyl jasmonate. Planta Med 76: P342 https://doi.org/10.1055/s-0030-1264640

9. JAMES JT, TUGIZIMANA F, STEENKAMP PA, DUBERY IA 2013 Metabolomic analysis of methyl jasmonate-induced triterpenoid production in the medicinal herb Centella asiatica (L.) Urban. Molecules 18: 4267-4281 https://doi.org/10.3390/molecules 18044267

10. THAKUR M, SOHAL BS 2013 Role of elicitors in inducing resistance in plants against pathogen infection: A review. ISRN Biochem, Article ID 762412.

11. YU ZZ, FU CX, HAN YS, LI YX, ZHAO DX 2006 Salicylic acid enhances jaceosidin and syringin production in cell cultures of Saussurea medusa. Biotechnol Lett 28: 1027-1031 https://doi.org/10.1007/s10529-006-9035-5

12. KHALILI M, HASANLOO T, KAZEMI TABAR SK, RAHNAMA H 2009 Influence of exogenous salicylic acid on flavonolignans and lipoxygenase activity in the hairy root cultures of Silybum marianum. Cell Biol Int 33: 988-994 https://doi.org/10.1016/j.cellbi.2009.06.003

13. KOVÁČIK J, GRÚZ J, BAČKOR M, STRNAD M, REPČÁK M 2009 Salicylic acid-induced changes to growth and phenolic metabolism in Matricaria chamomilla plants. Plant Cell Rep 28: 135143 https://doi.org/10.1007/s00299-008-0627-5

14. MUSTAFA NR, KIM HK, CHOI YH, VERPOORTE R 2009 Metabolic changes of salicylic acid-elicited Catharanthus roseus cell suspension cultures monitored by NMR-based metabolomics. Biotechnol Lett 31: 1967-1974

https://doi.org/10.1007/s10529-009-0107-1

15. YOUSEFZADI M, SHARIFI M, BEHMANESH M, GHASEMPOUR A, MOYANO E, PALAZON J 2010 Salicylic acid improves podophyllotoxin production in cell cultures of Linum album by increasing the expression of genes related with its biosynthesis. Biotechnol Lett 32: 1739-1743 https://doi.org/10.1007/s10529-010-0343-4

16. REZAEI A, GHANATI F, DEHAGHI MA 2011 Stimulation of taxol production by combined salicylic acid elicitation and sonication in Taxus baccata cell culture. International Conference on Life Science and Technology 3: 193-197

17. LOC NH, GIANG NT 2012 Effects of elicitors on the enhancement of asiaticoside biosynthesis in cell cultures of centella (Centella asiatica L. Urban). Chemical Papers 66: 642-648

18. DUČAIOVÁ Z, PETRULOVÁ V, REPČÁK M 2013 Salicylic acid regulates secondary metabolites content in leaves of Matricaria chamomilla. Biologia 68: 904-909 https://doi.org/10.2478/s11756-013-0217-z 
19. WEN PF, CHEN JY, KONG WF, PAN QH, WAN SB, HUANG WD 2005 Salicylic acid induced the expression of phenylalanine ammonia lyase gene in grape berry. Plant Sci 169: 928-934 https://doi.org/10.1016/j.plantsci.2005.06.011

20. CHAMAN ME, COPAJA SV, ARGANDONEA VH2003 Relationships between salicylic acid content, phenylalanine ammonialyase (PAL) activity, and resistance of barley to aphid infestation. J Agric Food Chem 51: 2227-2231

https://doi.org/10.1021/jf020953b

21. LI GJ, WANG SC, XIA K, ZHOU X 2003 Effect of yeast elicitor and salicylic acid on the fluctuation of phytohormone contents in Ti-transformed Salvia miltiorrhiza cell cultures. Plant Growth
Regulation 39: 27-32

https://doi.org/10.1023/A:1021838918280

22. RADCHENKO SV, ZVEREVA EV, FEDOREYEV SA, ZHURAVLEV YN 2002 Effect of salicylic acid, methyl jasmonate, ethephon and cantharidin on anthraquinone production by Rubia cordifolia callus cultures transformed with the rolB and rolC genes. J Biotech 97: 213-221 https://doi.org/10.1016/S0168-1656(02)00067-6

23. LOC NH, GIANG NT, HUY ND 2016 Effect of salicylic acid on expression level of genes related with isoprenoid pathway in centella (Centella asiatica (L.) Urban) cells. 3 Biotech 6: 86 doi: 10.1007/s13205-016-0404-z 